\title{
A Iniciação em Técnicas de Clown (Palhaço) como Dispositivo de Encontro Consigo e com o Outro.
}

\author{
Guedes, Amanda Kamylle Cavalcanti; França Neto, Jacqueline de; Silva, Nildienny \\ Alves da; Gomes, Bruno Severo \\ Universidade Federal de Pernambuco — amanda.cavalcantig@hotmail.com
}

Introdução a palhaçoterapia é um projeto de extensão destinado aos estudantes de saúde que visa a humanização no atendimento hospitalar. Através do ritual de iniciação e da linguagem do palhaço, os estudantes passam por várias dinâmicas e ações que, além de promover a reflexão e o autoconhecimento, mostram a relação horizontal entre o paciente e o profissional. Terminadas as oficinas, os estudantes passam a fazer intervenções nos hospitais ficando mais próximos da realidade do seu futuro local de trabalho. Objetivos o projeto tem como objetivo trabalhar a sensibilidade dos estudantes por meio do papel e significado do clown, fazendo-os refletirem sobre a forma de atuação como futuros profissionais e sobre seus erros, medos e perspectiva de mundo. Buscou-se também treinar o foco e a atenção, para que os estudantes estejam sempre alerta e disponíveis ao encontro com o outro e devido ao elevado número de estímulos no âmbito da saúde. Métodos para concretizar tais objetivos houve a realização da oficina de iniciação em técnicas de clown (módulo 1) ministrada por um instrutor (monsieur) em 12 encontros, computando carga horária total de 48 horas. Os encontros foram divididos nos módulos jogos, físico e estético. Durante as oficinas foi usado o diário de bordo, instrumento que continha as impressões de cada um sobre a oficina, que todos liam em círculo no começo de cada encontro. Resultados: no decorrer da oficina e no seu encerramento, foi possível verificar a mudança no olhar de cada participante. Houve um processo de aceitação pessoal, no qual os erros e limites de cada um foram trabalhados e ressignificados, tornando-os pessoas mais confiantes em si e abertas ao encontro com o desconhecido. Conclusões: a imperfeição e aspecto visual do palhaço se tornam eficazes meios de percepção das limitações dos seres humanos, a partir da reflexão sobre si e da aceitação dos erros e defeitos pessoais o olhar direcionado ao outro se torna mais leve e humano. Quando há o entendimento de que no hospital existem semelhantes, não faz sentido um atendimento verticalizado tanto com os pacientes quanto com a própria equipe de profissionais. o encontro humanizado com o outro hospitalizado se dá pelo entendimento de que a pessoa não é sua doença, do mesmo jeito que os profissionais, são seres com medos, erros, desejos e sonhos

Guedes, Amanda Kamylle Cavalcanti; França Neto, Jacqueline de; Silva, Nildienny Alves da; Gomes, Bruno Severo. A Iniciação em Técnicas de Clown (Palhaço) como Dispositivo de Encontro Consigo e com o Outro. In: Anais do Congresso Internacional de Humanidades \& Humanização em Saúde [= Blucher Medical Proceedings, num.2, vol.1]. São Paulo: Editora Blucher, 2014. ISSN 2357-7282 DOI 10.5151/medpro-cihhs-10522 